\title{
An Alternative Home? \\ ASEAN and Pacific Environmental Migration
}

\author{
Gil Marvel P.Tabucanon \\ Macquarie University
}

\begin{abstract}
ASEAN is in a unique position to push for greater global awareness and action for the vulnerable Pacific populations facing the possibility of relocation. Yet, it is strangely silent on the issue. ASEAN has both moral and legal obligation not to turn its back on its Pacific neighbors. ASEAN is proximate to many Pacific nations, and it has both the resources and landmass to help: two of the world's largest archipelagos are ASEAN members. Morally, the obligations of humanity and justice require larger and more developed states to aid and assist their more vulnerable neighbors. Legally, ASEAN may learn from the African Union (AU) experience. While AU accepted the UN Refugee Convention definition of 'refugee,' it expanded it to include those compelled to leave their country owing to 'events seriously disturbing public order.' Many scholars believe this includes the environmentally displaced.
\end{abstract}

ASEAN can choose to take the easy path of insularity and parochialism as regards the looming issue of environmental migration, or it can take the high road by transforming itself into a dynamic regional actor pushing for clear policies on how to address it. Displacements are by nature traumatic and carry with them the impoverishments of landlessness, joblessness, homelessness, marginalization, increased morbidity and mortality, food insecurity, loss of access to common property resources, and social disarticulation. ASEAN can do much to help its vulnerable neighbors. It is a strong voice in the international community asking it to help address the issue.

\section{Introduction}

Environmental changes are among the most serious threats faced by the world today. Yet, negotiations focus more on mitigation and less on adaptation, in spite the fact that potentially, the 'greatest single impact' of environmental change will be on 'human migration and displacement' (IPCC 1990). While migration would not be an only response to environmental changes, as affected populations may choose to adapt in situ or simply do nothing, yet it is a likely response for those whose homes and means of livelihood are within vulnerable locations. Still migration, as an adaptation response has rarely, if at all, reached national and regional agendas. While most migrations are projected to be temporary and internal with a rural to urban or coastal to higher ground mobility pattern, this is only true of larger islands and, generally, for those experiencing short term environmental events (Campbell \& Bedford 2012). For long-term processes, however, such as rising sea levels or irreversible salination of 
fresh water reserves rendering low lying atoll countries uninhabitable, the prospect of an international relocation will have to be considered.

This study examines an aspect of adaptation, namely the role of the Association of Southeast Asian Nations (ASEAN) vis-à-vis the vulnerable Pacific island populations. The use of ASEAN in this paper is not limited to the regional association strictly, but includes its ten member countries individually. ASEAN is not new to massive displacements at both regional and international levels. For instance, ASEAN received, and helped facilitate the international resettlement of, Indochinese 'boatpeople' in the 70s and 80s. While the Indochinese refugee situation was triggered by political and not environmental causes, ASEAN's response to the crisis -in particular its resort to international collaboration - provides important lessons for environmentally-induced migrations in the Pacific.

A closer interpretation of international law documents and principles (which, though not binding, have persuasive force), considerations of humanity and political philosophy culled from various juristic writings point to an increased ASEAN involvement, if not downright 'obligation' beyond state borders. Climate change is a global phenomenon requiring global response. It mandates progressive thinking, perhaps a veering from traditional realist to more cosmopolitan considerations and modes of problem solving. ASEAN may choose to respond from a parochial perspective by ignoring wider processes, or failing to heed the lessons of the past; or it may choose to transform itself into a relevant Asia-Pacific regional actor in addressing the globalizing effects of climate and environmental changes.

The paper is structured as follows: First, an overview of ASEAN, and Pacific environmental situation. Second, a discussion on state obligations beyond national and regional borders using ASEAN's experience on international mass migration from Vietnam, Cambodia and Laos (then non-ASEAN countries) as a learning experience for ASEAN should mass displacemenst occur, this time due to environmental factors. Third, the paper identifies key challenges in coming up with appropriate policies relative to the Pacific environmental situation. The paper concludes that a globally relevant ASEAN can help raise collective consciousness and action in rallying the international community to address climatic and environmental vulnerabilities. 


\section{Overview}

\section{ASEAN}

Since its founding more than 40 years ago, ASEAN has proven to be a resilient regional association that has grown in reach and vision. From five nations founding the association on August 8, 1967, namely Indonesia, Malaysia, the Philippines, Singapore and Thailand, it has since added five more to its membership: Brunei (1984), Vietnam (1995), Myanmar and Laos (both in 1997), and Cambodia (1999). East Timor is expected to be the $11^{\text {th }}$ member. From a mere joint political declaration, ASEAN has transformed itself into a legal entity by signing the 20 November 2007 ASEAN Charter - the region's constitution - which was fully ratified by December 2008. The Charter aims to strengthen the 'rule of law, and to promote and protect human rights' (Art.1.7), reaffirms the region's upholding of 'international law, including international humanitarian law' (Art 2.2) and the 'centrality of ASEAN in external political, economic, social and cultural relations while remaining actively engaged, outwardlooking, inclusive and non-discriminatory’ (Art 2.2).

\section{The Pacific}

For millennia, Pacific Islanders have moved across their vast region in search of opportunities, to satisfy a personal sense of adventure or else, to look for safe havens from natural or human-induced threats. Recent events and processes, however, suggest that migration triggered by environmental changes is expected to increase significantly over the coming years (IOM 2009). The Pacific region with its low-elevation island nations dispersed in a vast ocean setting makes it particularly vulnerable to challenges from the physical environment. The region is predicted to be among those where the adverse effects of environmental changes can be felt the most (Locke 2009). Climate and environmental changes are expected to have significant impacts on all the countries of the Pacific region, particularly the small atoll countries of Kiribati, the Marshall Islands, Tokelau and Tuvalu. This does not mean the larger island countries are not significantly vulnerable. The capital cities of Fiji, Solomon Islands, Papua New Guinea and Vanuatu, not to mention other areas of heavy population and infrastructure concentration, are located along the coasts thereby exposed to long-term climatic processes. But while larger islands have higher grounds for populations to flee to, this option is not available to low-lying atoll nations. Given the possibility of even a 'moderate amount of climate change over the next century,' atoll countries may ultimately become unsustainable as human habitations (Barnett and Adger 2001). 
While the extent of impacts of environmental change is still subject to debate, plans for proactive migration of human populations are emerging. The Kiribati government approved the purchase of 2,282 hectares of land in Vanua Levu Island, Fiji, in 2012. Extending '10 km inland from the coast' it has the potential for 'supporting both agricultural as well as fisheries development' (Campbell and Bedford 2012). While the land is for investment purposes, it is 'certainly one of a number of options for future residence for a central Pacific people who have long had to grapple with environmental uncertainty in their low-lying coral islands' (Campbell and Bedford 2012). Kiribati's President, Anote Tong, spoke in 2005 before the $60^{\text {th }}$ Session of the United Nations General Assembly on the need for atoll countries to consider relocation of their populations. For Watson, former Chair of the Intergovernmental Panel on Climate Change (IPCC), one of the dangers of land loss and displacement of populations is the 'possible loss of whole cultures' (Watson 2000). Thus, should relocation become imperative, what must be ensured is not only the physical survival of the inhabitants, but the continuation of their cultural and traditional legacies (UN General Assembly 2008). Their preservation in case of in situ adaptation or possible re-creation in host states in case of relocation are among the matters ASEAN can include into its own agenda, or else help bring to the larger international community for consideration.

\section{Obligation beyond state and regional borders}

Do states have obligations beyond national or regional borders? The answer would have implications to ASEAN on matters of environmental vulnerabilities of countries beyond its member states borders. Extraterritorial obligations arise from various sources, among them historical ties and treaties. For instance, colonialism has left the Pacific region with a ‘complex legacy of legal and political associations’ (Opeskin \& MacDermott 2009). Under New Zealand's Citizenship Act of 1977, residents of New Zealand's former colonies, the Cook Islands and Niue (now self-governing countries in free association with New Zealand), are considered to be New Zealand citizens with open migration access to New Zealand and access to its social services. Under the Citizenship Act, inhabitants of Tokelau, a New Zealand territory, are ipso facto New Zealand citizens. This agreement has implications for environmental migration and has facilitated the movement of former colonial peoples to New Zealand following devastating environmental events. In 1990, Hurricane Ofa 'nearly necessitated an evacuation of the island [Niue] to New Zealand' (Barker 2000). Additionally, Hurricanes Val (1992) and Percy (2005) destroyed most of Tokelau’s agriculture and led to 
'severe food shortages' such that New Zealand had to relocate Tokelauans to New Zealand (Moore \& Smith 1995).

States cooperate and enter obligations with other states when it is in their interest to do so. From the rational choice parameters of realpolitik, states collaborate when direct or future benefits accrue. There will be an 'unwillingness to continue cooperation should it become unfruitful to do so' (Linklater 1977, p. 42). The Trans-Tasman Travel Arrangement allowing citizens of Australia or New Zealand to travel, live and work in each other's state, cannot only be explained in light of past historical ties, but the economic benefits of a hassle-free exchange of visits, not to mention workers, from English speaking nations with a similar level of development. Papua New Guinea, which was part of the Australian commonwealth, but whose level of economy is deemed lagging behind that of Australia was not granted privileges. An exception, due to close cultural and geographical ties, are Torres Strait islanders who by treaty are given visa-free access to travel to Australia's northern islands under the 1985 Torres Strait Treaty between Australia and Papua New Guinea. ${ }^{1}$

\section{Cosmopolitan considerations}

A corollary question would be, do states have an obligation to consider the needs of countries with whom they have neither historical ties, nor a reasonable expectation of economic benefits. I am referring in this instance to ASEAN vis-à-vis the environmentally vulnerable atoll countries of the Pacific. I will argue that ASEAN has an obligation when seen from a cosmopolitan rather than realist viewpoint. I will use historical, legal and humanitarian considerations why this is so.

\section{Historical}

It is helpful to examine past ASEAN practice regarding forced migrations. Southeast Asia is no stranger to internal and cross-border displacements from conflicts and environmental disasters. Among these are the 2004 tsunami that killed hundreds of thousands, and displaced over 1.6 million people of which more than 500,000 were from Indonesia (Meisl, Safaie et al. 2006). The 2008 Cyclone Nargis, Myanmar's worst storm in recorded history with over a hundred thousand dead and hundreds of thousands more displaced (Ozerdem 2010, p. 698.) In both cases, most of displacements were internal, with the displaced either returning of their homes or resettling in nearby villages (Gray 2010).

\footnotetext{
${ }^{1}$ The Treaty allows Torres Strait residents of Papua New Guinea short visits to the Torres Strait Islands within Australian territory for traditional purposes, such as fishing and other traditional activities.
} 
A well-known case of mass international displacements affecting ASEAN was the Indochina refugee crisis in the late 1970s. Although conventionally regarded as a situation triggered by conflict, the mass movements from Vietnam, Cambodia and Laos were in fact precipitated by a confluence of socio-economic factors, and not just conflict. In some ways, the experience demonstrates the distinction between conflict-induced migrants and those who were economically- or environmentally-displaced are far more blurred. For instance, what began as conflict - both regional and ethnic - resulted in 'poverty and resource scarcity' (Frost 1980, p.348). '[E]conomic grievances’ was a frequently cited reason for leaving, and over the years the movements were influenced by the pull of 'distant relative[s] abroad who left in earlier waves.' Thus, what 'started as a refugee flow [had] increasingly come to resemble a migration flow' (Suhrke 1981, p. 26).

Between 1975 and 1979 over 270,000 Indochinese arrived by boat in Southeast Asia and Hong Kong [see Table 1], which created economic and social strain in the host countries.

TABLE 1

Numbers of People arriving by Boat in Southeast Asia and Hongkong

\begin{tabular}{|c|c|}
\hline Year & Number \\
\hline 1975 & 377 \\
\hline 1976 & 5,248 \\
\hline 1977 & 15,657 \\
\hline 1978 & 85,544 \\
\hline 1979 & \\
January & 8,954 \\
February & 5,737 \\
March & 11,157 \\
April & 26,600 \\
May & 51,550 \\
June & 56,941 \\
\hline
\end{tabular}

Source: United Nations High Commissioner for Refugees (UNHCR) (Quoted in Frost 1980).

At the insistence of the United Nations High Commissioner for Refugees (UNHCR), the December 1978 consultative meeting on displaced persons in Southeast Asia was convened where Thailand called for a wider sharing of the resettlement burden and limit of period of stay in ASEAN countries (UNHCR 1978). In July1979, a follow up consultative Meeting on Refugees and Displaced Persons in Southeast Asia was held and resulted in the formalization of the burden sharing principle among ASEAN and western countries. The burden sharing agreement was significant. Except for the Philippines (and later, Cambodia), none among the ASEAN countries have acceded to the two main international refugee law instruments, 
namely the Convention Relating to the Status of Refugees (1951 Refugee Convention) and the Protocol Relating to the Status of Refugees (1967 Refugee Protocol) (Davies 2008). Legally thus, non-convention countries of Indonesia, Malaysia, Singapore and Thailand may consider Indochinese arrivals illegal aliens and refuse to grant asylum. Thailand refused over 42,000 Cambodian refugees in late June 1979 while Malaysia towed boats back to sea (Stein 1979). The July 1979 meeting resulted in an ASEAN commitment to non-refoulement and for the region to grant temporary asylum provided resettlement within third countries was assured (Stein 1997).

Two main refugee processing centers were established, one on Galang Island in Indonesia and the other in the town of Morong, Bataan, the Philippines. A refugee camp was also established on Bidong Island in Malaysia. Another condition for acceptance was for the United States and the international community to bear the financial burden of maintaining the centers. At the insistence of ASEAN foreign ministers, another international meeting was held in 1989 in response to a renewed outflow of people seeking better living prospects following the footsteps of relatives and friends already resettled in more developed countries. The meeting, called the 1989 International Conference on Indochinese Refugees (ICIR), produced the Declaration and Comprehensive Plan of Action (CPA) which now involved the source country Vietnam's cooperation. Thus, at the ICIR, Vietnam agreed to simultaneously control illegal boat departures for non-genuine refugees, while expanding opportunities of legal emigration from Vietnam under the Orderly Departure Program (ODP). The Vietnamese also agreed to accept returnees to be monitored by the UNHCR, and 'not to take punitive measures against them' (Frost 1980, p.9).

By the 1990s the refugee crisis had subsided. If anything ASEAN has 'successfully made the point that the Indochina refugee problem [was] an international problem, not solely, nor even primarily, a regional one' (Frost 1980, p. 29). More research needs to be done on the ramifications of the Indochinese refugee situation. Forced displacements triggered by whatever type or cause is a global problem requiring global solutions. For more than 15 years, ASEAN agreed to be the country of first asylum conditional on the international community’s sharing the ultimate burden of resettlement. Also, legal and diplomatic measures were taken to reduce the push factors that induced the people to leave. In the context of today's vulnerabilities from environmental factors, this lesson translates to strengthening measures for in situ adaptation to enhance resilience and prevent forced 
migration. Yet, should migration become necessary, as the ASEAN experience has shown, the international community's coordination becomes an element in the search for durable solutions.

\section{Legal}

Admittedly, neither ASEAN nor its member states have direct treaty, customary law or domestic law obligation to aid, much less admit, cross-border environmental migrants. Unlike the African Union which has arguably - at least on paper - provisions for environmentally displaced 'refugees, ${ }^{2}$ or Spain ${ }^{3}$ which signed a treaty admitting those affected by the volcanic eruption in Colombia for temporary and seasonal work, and, unlike Sweden ${ }^{4}$ and Finland ${ }^{5}$ which both have domestic laws recognizing non-national environmental migrants as a discrete category deserving protection, ASEAN's member states do not as yet have legal protections in place, beyond normal and pre-existing migration channels. Yet, a closer interpretation of international law documents and principles reveals ASEAN may be obliged to help. Granting, arguendo, the documents and principles do not bind, or if they bind, states may ignore them for them for want of a monitoring or enforcement body, still they are persuasive, and the international community may reasonably expect - if not demand compliance.

\footnotetext{
${ }^{2}$ OAU (1969). Organisation of African Unity Convention Governing the Specific Aspects of Refugee Problems in Africa, adopted on 10 September 1969 and entered into force 20 June 1974. Art 1 (2) Art 1 (2) states: 'The term 'refugee' shall also apply to every person who, owing to external aggression, occupation, foreign domination or events seriously disturbing public order in either part or the whole of his country of origin or nationality, is compelled to leave his place of habitual residence in order to seek refuge in another place outside his country of origin or nationality.' The definition could potentially include the environmentally displaced. In Africa, there is the regional practice of allowing those affected by natural disasters such as famine and drought to enter international borders. While some governments are careful not to characterize the practice as an outright obligation arising from the AU treaty definition, it may be argued that the definition can contribute to the development of the protection rights for the environmentally displaced on. See Edwards, A. 2006, 'Refugee Status Determination in Africa', African Journal of International and Comparative Law, vol.14, no.2.

${ }^{3}$ Colombian Temporary and Circular Labour Migration Scheme (TCLM). According to Noor, '[w] the Galeras volcano in southwest Colombia erupted, the TCLM programme, which targets different vulnerable communities, was used to provide a migration opportunity for thousands of affected people. This programme allowed them to temporarily migrate to Spain, where they could earn an income in seasonal harvest. Afterwards, the programme was also expanded to rural populations, whose crops and land are particularly vulnerable to floods, droughts and other environmental disruptions.' Nicole de Moor, Temporary Labour Migration for Victims of Natural Disasters: The Case of Colombia, paper prepared for UNU-EHS Summer Academy on Social Vulnerability, Hohenkammer, Germany, 25-31 July 2010

${ }^{4}$ Swedish Aliens Act, Ch 4, s.2(3) (2006).The Swedish Aliens Act, Chapter 4, Section 2(3) defines a 'person otherwise in need of protection' as an alien 'unable to return to the country of origin because of an environmental disaster.' Chapter 5, Section1 entitles 'persons otherwise in need of protection' to a 'residence permit.'

${ }^{5}$ Finnish Aliens Act, Ch. 6 s.109 (1) (2009).The Finnish Aliens Act, Chapter 6 Section109(1) on the other hand, grants '[t]emporary protection' to aliens in 'need [of] international protection and who cannot return safely to their home country or country of permanent residence, because there has been... an environmental disaster.' Temporary protection may be for a 'short duration,' and 'lasts for a maximum of three years in total.'
} 
The ASEAN nations and the small Pacific island states are members of the United Nations. As members they pledged to 'achieve international cooperation in solving international problems,' likewise in 'promoting and encouraging respect for human rights' ${ }^{6}$ The question is whether the obligation relates only to the state's population, or populations within their territories, or whether the obligation extends to peoples outside the state. What is settled is that under customary international law, broadly applying the principle of state responsibility, states must refrain from acts causing harm to another state. ${ }^{7}$ The prohibition to commit acts of genocide, piracy, slavery, torture and generally violation of peremptory norms (jus cogens) is a universal obligation, and applies to inter-state relations. These are however, mainly negative obligations.

The question arises: Do states have positive obligation towards other states? Under international human rights law, everyone has the right to life (UDHR 1948; ICCPR 1966). The right to life is one of the foundational principles of international relations. Likewise, every person has a right to adequate food, clothing, housing and the continuous improvement of living conditions, (ICESCR 1966) and everyone has the right not to be deprived of his or her means of subsistence (ICCPR 1966). While the right to life, like the right to food, is compellable as a negative right under international customary law, e.g. the right not to be killed or not to be intentionally starved as when another nations' food supply is cut off, it may not be compellable when expressed as a positive right, e.g. compel medical treatment when sick. Be that as it may, under General Comment No. 12 of the Committee on Economic, Social and Cultural Rights, '[s]tates have a joint and individual responsibility, in accordance with the Charter of the United Nations, to cooperate in providing disaster relief and humanitarian assistance in times of emergency, including assistance to refugees and internally displaced persons’ (UN Committee 1995). While internationally displaced environmental migrants are not included, they are not excluded, hence may be subsumed among those requiring 'disaster relief and humanitarian assistance.' It is submitted, that in the event of long-term environmental impacts of extreme weather rendering islands uninhabitable,

\footnotetext{
${ }^{6}$ UN Charter, art. 1(3), signed 26 June 1945, 59 Stat. 1031, T.s. No.993, 3 Bevans 1153, entered into force 24 October 1945. Under Art 1(3), among the purposes for which the United Nations was established was to 'achieve international co-operation in solving international problems of an economic, social, cultural, or humanitarian character, and in promoting and encouraging respect for human rights and for fundamental freedoms for all without distinction as to race, sex, language, or religion.' It is submitted that 'humanitarian' in this context is used in its generic, i.e. the promotion of human welfare generally, and not restricted to conflict situations.

${ }^{7}$ Trail Smelter Case (United States v. Canada), 3 R.I.A.A. 1905 (1941).
} 
humanitarian assistance includes not only food and medical supplies but the possibility of permanent relocation. While not all 10 ASEAN countries ratified the International Covenant on Civil and Political Rights (ICCPR) and International Covenant on Economic, Social and Cultural Rights (ICESCR), ${ }^{8}$ it may be argued the non-signatory countries are nonetheless bound to observe international human rights law principles under customary international law.

ASEAN is in a position of strength to promote the adoption of both international and regional legal frameworks relative to the environmental and human-mobility impacts of climate change. ASEAN's experience in the areas of environment and forced migration demonstrates its capacity. The ASEAN-brokered 2002 Agreement on Transboundary Haze which entered into force on 25 November 2003 is considered a global role model in tackling transnational haze issues and the 2004 ASEAN Declaration Against Trafficking in Persons explicitly addresses the issue of human trafficking particularly of women and children. While ASEAN may not solely bear the brunt of resettlement responsibility, it need not remain silent on the issue of cross border climate change displacements. For instance, the ASEAN Declaration on Environmental Sustainability recognizes the need to develop an ASEAN climate change initiative. Yet, it only goes as far as pushing for the building of environmentally sustainable cities, the promotion of alternative energy sources, energy efficiency and energy security (Yuen \& Kong 2009).

\section{Moral}

Beyond legal conceptions, does ASEAN have moral obligations towards environmentally vulnerable populations beyond state borders? The nature of justice and moral responsibilities between nationals of the same state has been the subject of rigorous philosophical inquiry. For instance, Rawls, in reviving the social contractarian tradition argued that while an equal distribution of natural talents and acquired wealth may not be avoided, justice requires natural talents to become a 'common asset' among those sharing a bond of membership in a society.

Those who have been favored by nature, whoever they are, may gain from their good fortune only on terms that improve the situation of those who have lost out. The naturally advantaged are not to gain merely because they are more gifted, but only to cover the costs of training and education and for using their endowments in ways that help the less fortunate as well. No one deserves his greater natural capacity nor merits a more favorable starting place in society. But it does not

\footnotetext{
${ }^{8}$ Malaysia, Singapore, Brunei and Myanmar have not ratified ICCPR or ICESCR; while Laos ratified the ICESCR and only signed but did not ratify the ICCPR. All other ASEAN member states ratified both treaties.
} 
follow that one should eliminate these distinctions. There is another way to deal with them. The basic structure of society can be arranged so that these contingencies work for the good of the least fortunate [the 'difference principle'] (Rawls 1971, p. 17).

But while notions of justice and moral obligations are more of less settled in a state setting, comparatively little attention has been directed to them in a global setting' (Opeskin 1995, p.20). Are the principles of justice and moral responsibility applicable in a world setting? If so, what are they and from where are they based. May humanity be regarded a single community? In this context, does ASEAN have moral obligation towards vulnerable Pacific nations which may have to consider the possibility of international relocation?

Most of us intuitively acknowledge a moral obligation to 'relieve human suffering or distress' when doing so would not equally endanger our life and limb (Opeskin 1996). Such an approach stems from our common humanity and is most manifest in one's instinctive almost reflexive - response to save a drowning person from a pool, either by ourselves or through another. Admittedly, the demand to respond to such a situation is more compelling within those closest to us: family, neighbors, community. Yet, visitors in a foreign land on their holidays would be equally pressed to save a drowning local child should they be in a proximate situation to do so. The obligation thus is not limited to blood relations or psychological proximity, but one rooted in our basic humanity, the sameness of the human condition we all share. Writing on the universal obligation to help famine victims of Bangladesh in the early 70's, Singer posits that such an obligation extends to individuals beyond state borders (Singer 1972). His argument is premised on the fact that suffering from lack of food and medicine is bad, and that it is within the power of other states to prevent or relieve the suffering in such a situation. Singer believes that the more privileged nations can do something to reduce the number of starving people without giving up the basic necessities themselves.

Governments across the region have expressed interest in human displacement. The InterGovernmental Asia-Pacific Consultations on Refugees, Displaced Persons and Migrants (APC), founded in 1996, provides a forum relevant to forced migration issues to explore opportunities for regional cooperation, while the ASEAN Inter-governmental Commission of Human Rights (AICHR) established in September 2009, identified migration among its concerns. In 2009, the Maritime Minister of Indonesia announced that Indonesia was 
considering renting out some of its islands to 'climate change refugees' (Holland 2009). The announcement augurs well for ASEAN and provides a counter-point to parallel considerations regarding environmental migrants as non-traditional threats to the region.

\section{Challenges to Long-term Resettlement}

Lack of common agreement

Among ASEAN's challenges in explicitly addressing environmental migration in general and Pacific environmental migration in particular is the lack of a common agreement on the definition of environmental migration. The conceptual, and consequently legal, parameters of the term are at most hazy and blur with existing definitions of 'refugee', 'internal displacees,' or 'labour, circular or seasonal migrants.' Displaced populations due to cyclones, volcanic eruptions and tsunamis have the refugee-like characteristics of being forced out of their homes due to life threatening factors. Yet, unlike refugees and refugee-like peoples, environmental migrants are not covered by an international legal framework. In international law, environmental migrants are not a 'formal category of people in need of special protection' (McAdam and Saul 2008); neither is there a 'coordinated legal and administrative system' to relocate them in a 'planned and orderly manner' (Millar 2007, p.71). There is as yet little international support for a new normative category (Kolmannskog 2009); and the difficulty of getting policy-makers to act cannot be underestimated (Sriskandarajah 2008, p.61).

ASEAN may learn from the African Union (AU) by expanding the definition of 'refugee.' While the AU accepted the UN Refugee Convention's definition of 'refugee,' it expanded it to include those compelled to leave their country owing to 'events seriously disturbing public order' (OAU 1969). The definition could potentially include the environmentally displaced. In Africa, there is the regional practice of allowing those affected by natural disasters such as famine and drought to enter international borders. While some governments are careful not to characterize the practice as an outright obligation arising from the AU treaty definition, it may be argued that the definition can contribute to the development of the protection rights for the environmentally displaced on 'humanitarian grounds under customary international law’ (Edwards 2006).

ASEAN may also learn from state practice where environmental migration policies are in place, albeit embryonic. Sweden and Finland have legislated protection mechanisms for victims of 'environmental disasters'. Swedish immigration policy names environmental 
migrants as a separate category of 'person in need of protection' (Swedish Aliens Act 2006). The Finnish Aliens Act grants residence permits to those who 'cannot return because of an armed conflict or environmental disaster’ (Finnish Aliens Act 2009). Further, an alien residing in Finland is issued with a 'residence permit on the basis of humanitarian protection if... he or she cannot return to his or her country of origin or country of former habitual residence as a result of an environmental catastrophe' Although the preparatory works to the Aliens Act state that the preferred option in environmental disasters is 'internal relocation and international humanitarian aid,' the Act expressly acknowledges that protection in Finland may become necessary (UNHCR 2009).

\section{Nature of environmental migration}

Another challenge for ASEAN policy makers is the nature of environmental migration. Much like other environmental problems such as sea and air pollution, the cause and effects of environmental displacements often transcend national borders. Yet, the existing structure of the international system is dominated by state-centrism. Based on international law principles of territorial integrity and sovereignty, States have full discretion as to who or who not to admit into their bounded territory (Zilbershats 2002). However, in an increasingly interconnected world with globalized problems this causes difficulties. Climate change and its effects respect no borders. ASEAN thus needs to find responsive paradigms and solutions that fit the global nature of the challenge.

One of ASEAN's strengths is it is already a step removed from strict state-centrism. By its founding it recognized that there are areas of endeavour within the region needing collective and collaborative responses. An example would be the previously discussed refugee crisis, when boatloads of Vietnamese, Cambodian and Laotian refugees spilled over to neighbouring ASEAN countries. Ultimately, the refugees were taken in, albeit temporarily, while awaiting resettlement in third countries, and refugee centers were established in Indonesia, Malaysia and the Philippines.

A humanitarian imperative rarely determines a host country’s resettlement decision. Instead these are influenced by political expediency, media clamour, ideology as well as shared history and culture. Yet, this should not prevent the ASEAN from learning from countries who relaxed border controls following environmental catastrophes, albeit devoid of a shared colonial past. 
Following the December 2004 Asian tsunami, Canada announced it was fast tracking landedimmigrant status for those affected. By March 2005, about 1,000 applications had been expedited. The Department of Immigration also announced it would expedite family sponsorships of persons coming from the affected areas. Canadian immigration officials also met with members of the Indonesian, Indian, Somali and Sri Lankan communities in Toronto to coordinate the role these communities would have in assisting the resettlement of the migrants. Australia likewise fast-tracked migration applications as well as placed priority on the handing of temporary protection visas for the displaced tsunami victims (Laczko and Collett 2005).

\section{Prospects for Pacific Peoples}

Relocated communities often find themselves in a 'state of discontent' with many finding themselves wanting to return to their home islands (Campbell, Goldsmith et al. 2005). A 'sense of loss' is especially pronounced in environmental disasters, where the relocated populations are suddenly uprooted from their traditional lands and systems (Kirsch 2001). There is a strong bond between the Pacific islanders; in most cases people and land are 'inseparable’ (Campbell, Goldsmith et al. 2005). While regular migration options depend on individual decisions and the 'fit' between the migrants' qualifications and host state's requirements, community relocation whether in the ASEAN region or elsewhere presents crucial operational if not ethical questions, among them are as follows:

1. Responsibility - Who is responsible for the relocation? Do neighboring states have moral and legal obligation under human rights principles to facilitate relocations when necessitated? Past relocations were initiated by government and development agencies following natural calamities. These relocations were of a humanitarian and temporary nature. Evacuees were expected to return after the disaster has passed. For long-term processes such as desertification and possible sea-level rise, permanent relocation is the only option. Many of these relocations are expected to cross international borders. The resettlement of Carteret Islander families in Bougainville was made possible by the Papua New Guinea government which has jurisdiction over both sending and receiving islands (Parry 2006). For the smaller Pacific states, their only recourse is international relocation. 
2. Timing - Relocation is a complex process that requires entire communities to be uprooted. As such, it requires not only preparation but physical and psychological readiness on the part of both the relocatees and the host communities. Considering that natural disasters exacerbated by climate change can happen any time, an early preparation is imperative. Kelman suggests an early planning but delayed departure scheme (Kelman 2006). This means contingency measures such as the identification or advance purchase of relocation sites would have to be done, but delayed departure when necessary. The delayed departure permits 'psychological and logistical' readiness and saves ‘decades of productive island life’ (Kelman 2006).

3. Funding - Relocation involves costs. These can include preparation and transportation of communities, and the setting up of infrastructure in the relocation site. This includes roads, housing and utilities. Eventually, provisions for the setting up of schools, health centers would have to be made available as well. In the case of Banaba, a resettlement trust fund has been set up years prior to the relocation. This was made possible out of Banaba island's phosphate royalties. Funding for climate change adaptation may require multilateral cooperation. Although criticized by some as difficult for third world nations to access, the United Nations administered Global Environment Facility GEF Trust Fund, which includes the Least Developed Countries Trust Fund (LDCTF) and Special Climate Change Trust Fund (SCCF) offers promise for countries which may require resettlement due to climate change.

Already, the government of Indonesia has set up the Indonesia Climate Change Trust Fund (ICCTF) which supports climate change mitigation and adaptation projects within Indonesia. The ICCTF receives contributions from bilateral and multilateral donors for the purpose. The Indonesian experience can be used as a blue-print for the establishment of an ASEAN Climate Change Trust Fund. This ASEAN fund may already include provisions for possible resettlement options within and outside of ASEAN borders.

4. Relocation site - Australia and New Zealand are often mentioned as possible resettlement sites due to proximity and level of economic development. A disadvantage would be possible loss of an island culture if resettlement is made in metropolitan cities, whereas an island in Indonesia or the Philippines would more or 
less provide similar tropical island surroundings. This means arrangements would have to be made involving multilateral actors. ASEAN would be in a good position to broker logistics and preparation: from identifying temporary processing centers similar to the Bataan refugee center pending final placements, to the purchase or lease of tracts of agricultural lands as relocation sites; when feasible, outright ceding of existing islands or creation of artificial islands may be considered. Territorial claims aside, Layang-Layang island in the Spratly Islands was artificially created by Malaysia by way of reclaiming the shallow sea in between two reefs.

\section{Conclusion}

Around 10 per cent - 550 million- of the world's population live on its 180,498 islands, of which some 30,000 are in the Pacific. More than one fifth or 22 per cent of the world's sovereign states are exclusively island states (Kelman 2006). Although islands occupy just 1.86 per cent of the Earth's land surface area, 13.1 per cent -or 106 out of 812 - of UNESCO's World Heritage sites are on islands.

The various cultural heritages of the Pacific Islands are important in their own right, and the necessity of preserving them cannot be underestimated. Islands yield a rich array of the world's languages, beliefs, livelihood systems as well as unique social, political and governmental structures. Pacific island states account for an unusually high percentage of the world's linguistic and cultural output. Over a third of all known languages are spoken in the four Pacific countries of the Melanesian region: New Caledonia, Papua New Guinea, the Solomons and Vanuatu (Pernetta 1992). Pacific islands are also home to distinctive mores, cultures, indigenous knowledge, and ecological features that cannot be duplicated elsewhere. Islanders' indigenous knowledge, albeit increasingly diminishing in the modern age, mitigates extreme impacts of natural disasters. The indigenous knowledge of Solomon Islanders helped residents recognize impending signs of the 2 April 2007 tsunami thereby reducing casualties (McAdoo, Moore et al. 2009). While the island characteristics of isolation, low elevation, small size and resource base make them more vulnerable to environmental threats, yet, their isolated societies also produce tight kinship networks and a strong sense of community that help address challenges cohesively (Howorth 2005).

That the Pacific is extremely vulnerable to long-term environmental processes cannot be overemphasized. In Kiribati where groundwater is the 'main source of drinking water' on most 
islands, residents have been 'forced to migrate temporarily to areas with higher rainfall' (Roy \& Connell 1991). Some of these processes are said not to be caused by climate change but by neglect, short-sightedness in implementation of construction projects and mismanagement. Connell argues that in Tuvalu, for instance, the construction of roads between islands had blocked the natural lagoon to ocean channels; that the dredging and sea wall construction, airport runway sealing and land reclamation have 'all transformed the topography of tiny islands' and 'ensured that the effects of storms and high tides are different to those in earlier times' (Connell 2003, p.104). In any case, low lying atoll states such as Tuvalu remain vulnerable to long term environmental processes such as climate change.

ASEAN is in a unique position to push for heightened global awareness and action for the vulnerable Pacific populations facing the possibility of relocation. Yet, it is strangely silent on the issue. ASEAN has both moral and legal obligation not to turn its back on its Pacific neighbors. Morally, ASEAN is geographically, albeit not politically, part of the Pacific region. It is proximate to many Pacific nations, and it has both the resources and landmass to help: two of the world's largest archipelagos are ASEAN members. The obligations of humanity and justice require larger and more developed states aid and assist their more vulnerable neighbors. Calamity becomes an injustice if those who could have 'undertaken preventive action' were remiss, or 'failed to try’ (Sen 2009). Legally, international human rights instruments mandate everyone to observe the duty to preserve life, the right to life being one of the foundational principles of international relations. ASEAN may learn from the African Union (AU) experience. While AU accepted the UN Refugee Convention definition of 'refugee', it expanded it to include those compelled to leave their country owing to 'events seriously disturbing public order.' Many scholars believe this includes the environmentally displaced.

ASEAN can choose to take on the easy path of insularity and parochialism as regards the looming issue of environmental migration, or it can take the high road by transforming itself into a dynamic regional actor pushing for clear policies on how to address it. Displacements are by nature traumatic and carry with them the impoverishments of landlessness, joblessness, homelessness, marginalization, increased morbidity and mortality, food insecurity, loss of access to common property resources, and social disarticulation (Cernea \& McDowell 2000). ASEAN can do much to help its vulnerable neighbors. With its archipelagos and off shore islands it can open its doors to vulnerable Pacific populations. Resettlement may be permanent or else temporary, pending determination of the 
environmental migrants’ permanent home, as in the case of Vietnamese and Cambodian refugees. At the very least, ASEAN can help raise global consciousness and awareness in rallying the international community to collectively address the issue.

\section{Acknowledgements}

I would like to thank the anonymous reviewers for their supportive and helpful comments.

\section{References}

Associated Press 2010, Haiti Raises Earthquake Toll to 230,000. The Washington Post.

ASEAN (Association of Southeast Asian Nations) 2007, Charter of the Association of Southeast Asian Nations, signed on 20 November 2007.

ASEAN Regional Forum 2010, ASEAN Regional Forum Documents Series 2006 -2009, ASEAN Secretariat, Jakarta.

Australia, Senate Select Committee Report 2004, The Senate Select Committee Report on Ministerial Discretion in Migration Matters, Commonwealth of Australia.

Australia, 1995, Torres Strait Treaty Australia-Papua New Guinea, article 11(1), Australian Treaty Series 1985 No 4.

Australian Law Reports 1996,Ozmanian v. Minister for Immigration Local Government and Ethnic Affairs, ALR 103, p. 137.

Australian Law Reports 1998, Re Bedlington and Another: Ex parte Chong, ALR 436, p. 157.

Barker, J. 2000, 'Hurricanes and Socioeconomic Development on Niue Island',Asia Pacific Viewpoint,vol. 41, no.2.

Barnett,J.\&Adger, W. N. 2001, Climate Dangers and Atoll Countries, Tyndall Centre for Climate Change Research, Working Paper No. 9.

Campbell, J. \& Bedford, R. 2012, 'Oceania', in Piguet, E. and Laczko, R (eds), People on the Move in a Changing Climate: Comparing the Impact of Environmental Change on Difference Regions of the World, Springer.

Campbell, J., Goldsmith, M. et al. 2005, Community Relocation as an Option for Adaptation to the Effects of Climate Change and Climate Variability in Pacific Island Countries (PICs), AsiaPacific Network for Global Change Research.

Cernea, M. 2000, Risks and Reconstruction: Experiences of Resettlers and Refugees. World Bank, Washington, D.C.

Cernea, M. \& McDowell, C. 2000, Risks and reconstruction: Experiences of Resettlers and Refugees. The World Bank, Washington, D.C..

Connell, J. 2003, 'Losing Ground? Tuvalu, the Greenhouse Effect and the Garbage Can', Asia-Pacific Viewpoint, vol.44, no.2.

Davies, S. 2008, Legitimizing Rejection: International Refugee Law in Southeast Asia, Martinus Nijhoff, Boston.

de Moor, N. 2010, Temporary Labour Migration for Victims of Natural Disasters: The Case of Colombia, paper prepared for UNU-EHS Summer Academy on Social Vulnerability, Hohenkammer, Germany, 25-31 July 2010.

Edwards, A. 2006, 'Refugee Status Determination in Africa', African Journal of International and Comparative Law, vol.14, no.2.

Elliot, L. 2012, Climate Change and Migration in Southeast Asia: Responding to a New Human Security Challenge, Asia Security Initiative Policy Series, Working Paper No. 20, February 2012.

Finnish Aliens Act 2009, Finnish Aliens Act, Ch. 6 s.109 (1).

Frost, F. 1980, 'Vietnam, ASEAN and the Indochina Refugee Crisis', Southeast Asian Affairs, 1980, pp. 347-367. 
Gray, C. 2010, Environmental Refugees or Economic Migrants?, Population Reference Bureau, Washington, D.C.

Holland, S. 2009, Indonesia's Rent-an-Island Answer to Climate Change, ABC News, 3 June 2009.

Howorth, R. 2005, Islands, Isolation and Vulnerability, Know Risk,. Tudor Rose Publications and the International Strategy for Disaster Reduction, Leicester.

ICCPR 1966, International Covenant on Civil and Political Rights (adopted 16 Dec 1966, entered into force 23 March 1976) 999 UNTS 171

ICESCR 1966, International Covenant on Economic, Social and Cultural Rights (adopted 16 December 1966, entered into force 3 January 1976) 993 UNTS 3 (ICESCR) art 11.

IOM 2009,Migration, Climate Change and the Environment:International Organization for Migration Policy Brief, International Organization for Migration.

IPCC 1990, First Assessment Report of the Intergovernmental Panel on Climate Change, Intergovernmental Panel on Climate Change.

Kelman, I. 2006, 'Island security and disaster diplomacy in the context of climate change', Les Cahiers de la Securité, vol.63, pp. 61-94.

Kirsch, S. 2001, 'Lost Worlds: Environmental Disaster, Culture Loss and the Law', Current Anthropology, vol. 42, no.2.

Kolmannskog, V. 2009, To what extent can existing forms of legal and operational protection apply to climate change-related displacement in general and cross-border displacement in particular? RSC Workshop on Environmental Change and Migration, University of Oxford.

Laczko, F. \&. Collett, E. 2005, 'Assessing the tsunami's effects on migration, Migration Information Source, Migration Policy Institute.

Linklater, A. 1977, Obligations Beyond the State, PhD Thesis, the London School of Economics and Political Science.

Locke, J. 2009, 'Climate change-induced migration in the pacific region: Sudden crisis and long-term developments', The Geographical Journal, vol. 175, no.3.

McAdam, J. and Saul, B. 2008, An Insecure Climate for Human Security? Climate-Induced Displacement and International Law, Sydney Centre Working Paper 4.

McAdoo, B., Moore, A. et al. 2009, 'Indigenous knowledge and the near field population response during the 2007 Solomon Islands tsunami', Natural Hazards, vol.48, no.1, pp.73-83.

Meisl, C., S. Safaie, et al. 2006, 'Housing reconstruction in Northern Sumatra after the December 2004 Great Sumatra Earthquake and Tsunami', Earthquake Spectra, vol.22, no. 3)

Millar, I. 2007, 'There's no place like home: Human displacement and climate change', Australian International Law Journal, vol.14, no. 71.

Moore, E. \& Smith, J. 1995, 'Climate change and migration from Oceania: Implications for Australia, New Zealand and the United States of America', Population and Environment, vol. 17, no.2.

New Zealand Citizenship Act 1977 Art. 29, sec. 1 (Cook Islands), 2 (Niue) and 3 (Tokelau), Citizenship Act 1977, 061 Commenced: 1 January 1978.

OAU 1969, Organisation of African Unity Convention Governing the Specific Aspects of Refugee Problems in Africa, adopted on 10 September 1969 and entered into force 20 June 1974. Art 1 (2)

Opeskin, B. 1995, 'Foreign Aid in a Bounded World, An Appraisal of the Universalistic Moral Tradition', Bulletin of the Australian Society of Legal Philosophy1995, no.6.

Opeskin, B. 1996, 'The Moral Foundations of Foreign Aid', World Development, vol. 24, no. 1, pp 21-44.

Opeskin, B. and T. MacDermott 2009, 'Resources, population and migration in the Pacific: Connecting Islands and Rim', Asia Pacific ViewPoint vol. 50, no.3.

Ozerdem, A. 2010, 'The 'responsibility to protect' in the context of natural disasters: another excuse for interventionism? Nargis Cyclone, Myanmar', Conflict, Security and Development, vol.10, no.5, pp. 693-713.

Parry, R. L. 2006, Drowning Worlds. The Times, 21 December.

Pernetta, J. 1992, 'Impacts of climate change and sea-level rise on small island states: National and international responses', Global Environmental Change, vol. 2, no. 1.

Rawls, J. 1971, A Theory of Justice, Harvard University Press, Cambridge, Mass. 
Roy, P. \& Connell, J. 1991, 'Climatic change and the future of atoll states', Journal of Coastal Research, vol.74, pp. 1069 ff.

Sen, A. 2009, The Idea of Justice, Penguin Books.

Singer, P. 1972, 'Famine affluence and morality’, Philosophy and Public Affairs, vol.1, no.3, 1, pp 229-243.

Smith, D. \& Vivekananda, J. 2007, A Climate of Conflict: the Links Between Climate Change, Peace and War, International Alert, London.

Sriskandarajah, D. 2008, 'Changing climate, changing policies', Forced Migration Review, vol. 31, no.6.

Stein, B. 1979, 'The Geneva Conferences and the Indochinese Refugee Crisis', International Migration Review, vol 13, no. 4.

Stein, B. 1997, Regional Efforts to Address Refugee Problems, paper presented at the 1997 Annual Meeting of the International Studies Association, Toronto, 21 March 1997.

Suhrke,A. 1981, 'Indochinese Refugees: Impact on ASEAN and U.S. Policy', Contemporary Southeast Asia, vol. 3 no. 1.

Swedish Aliens Act 2006, Swedish Aliens Act, Ch 4, s.2(3).

Taylor, S. 1995, 'Soveriegn Power at the Border', Public Law Review, vol. 55.

UDHR 1948, Universal Declaration of Human Rights, art 3, United Nations.

UN Committee on Economic, Social and Cultural Rights1995, General Comment No. 12, States and International Organizations, U.N. Doc. No. E/C. 12/1995/5

UN General Assembly 2008, United Nations General Assembly, 63rd session, 9th plenary meeting (25 September 2008) UN Doc A/63/PV.9, Mr Marcus Stephen, President of the Republic of Nauru.

UNHCR 1978, United Nations High Commissioner for Refugees, Draft Summary Report: Consultative Meeting with Interested Governments on Refugees and Displaced Persons in Southeast Asia, Geneva 11-12 December 1978, HCR/50B/15/78

UNHCR 2009, Forced Displacement in the Context of Climate Change: Challenges for States under International Law. 6th session of the Ad Hoc Working Group on Long Term Cooperative Action under the Convention (AWG-LCA 6)12, Office of the United Nations High Commissioner for Refugees.

U.S. Citizenship and Immigration Services, Department of Homeland Security, Humanitarian Parole, Requirements for Parole, available at http://www.uscis.gov/portal/site/uscis/menuitem.eb1d4c2a3e5b9ac89243c6a7543f6d1a/?vgnext oid=accc3e4d77d73210VgnVCM100000082ca60aRCRD\&vgnextchannel=accc3e4d77d73210 VgnVCM100000082ca60aRCRD (last visited 26 September 2012.)

US Citizenship and Immigration Services 2010, Special Humanitarian Parole Program for Haitian Orphans Draws to a Close at Request of Haitian Government, USCIS.

US Compact of Free Association Act 2003, art. IV, sec 141 (A)(1)(2)(3), U.S. Public Law 108-188.

Watson, R. 2000, Presentation of the Chair of the Intergovernmental Panel on Climate Change at the Sixth Conference of Parties to the United Nations Framework Convention on Climate Change, November 13, 2000, http://www.ipcc.ch/graphics/speeches/robert-watson-november-132000.pdf, last visited 2 February 2013

Yuen, B. and L. Kong 2009, 'Climate change and urban planning in Southeast Asia', Sapiens Revues, vol. 2, no. 3.

Zagor, M. 2010, 'Playing God - Ministerial discretion in migration law', Legaldate, vol.3.

Zilbershats, Y. 2002, The Human Right to Citizenship: Free Movement, Forced Migration, and Human Security, Transnational Publishers. 